\title{
Cyclone, Salinity Intrusion and Adaptation and Coping Measures in Coastal Bangladesh
}

Mr. Sebak Kumar Saha ${ }^{+}$

\section{Abstract}

Although households in the coastal areas of Bangladesh undertake various adaptation and coping measures to minimise their vulnerability to cyclone hazards and salinity intrusion, these autonomous measures have received little attention in the past. However, the Government of Bangladesh has recently emphasised the importance of understanding these measures so that necessary interventions to make households more resilient to natural hazards and the adverse impacts of climate change can be introduced. This paper, based on secondary sources, explores adaptation and coping measures that households in the coastal areas of Bangladesh undertake to minimise their vulnerability to cyclone hazards and salinity intrusion. This paper shows that many of the adaptation and coping measures contribute to making households less vulnerable and more resilient to cyclone hazards and salinity intrusion, although some coping measures do the opposite as they reduce households' adaptive capacities instead of improving them. This paper argues that the adaptation and coping measures that contribute to reducing households' vulnerability to natural hazards need to be supported and guided by the government and NGOs to make them more effective. Additionally, measures that make households more vulnerable also need to be addressed by the government and NGOs, as most of these measures are related to and constrained by both poverty, and because the households have little or no access to economic opportunities.

Keywords: Cyclone, Salinity intrusion, Adaptation and coping measures, Bangladesh

\footnotetext{
${ }^{\dagger}$ PhD Candidate, School of Culture, History and Language, Room 7239, Coombs Building, College of Asia and the Pacific, The Australian National University, Australia and Assistant Professor, Department of Sociology, Shahjalal University of Science and Technology, Sylhet, Bangladesh,Email:sebak.kumar@gmail.com

CSaha 2017. This is an Open Access article distributed under the terms of the Creative Commons Attribution License (http://creativecommons.org/licenses/by/2.0), which permits unrestricted use, distribution, and reproduction in any medium, provided the original work is properly cited.
} 


\section{Introduction}

Bangladesh, which is one of the most disasterprone countries in the world, regularly experiences various types of natural hazards, including floods, cyclones and storm surges, tornados, river-bank erosion, droughts, landslides, and earthquakes (Ministry of Environment and Forests [MEF], 2005; Disaster Management Bureau [DMB], 2010). Cyclonic storm surges and floods are major killers and the cause of most direct and indirect damage in Bangladesh (MEF, 2005). Furthermore, climate change will exacerbate many of the existing natural hazards that the country faces (MEF, 2005; Ministry of Environment and Forests [MEF], 2009; Ministry of Disaster Management and Relief [MDMR], 2015) (see Table I). Climate change will lead to an increase in both the frequency and intensity of climatic events, although it will not necessarily create new hazards. Bangladesh's low level of social and economic development, inadequate infrastructure, lack of institutional capacity, and higher dependency on the natural resource base increases its susceptibility to existing natural hazards and the adverse effects of climate change (MEF, 2005), with the population living in the coastal areas being more exposed to these impacts than those living in other parts of Bangladesh (MEF, 2005; Parvin, Takahashi, \& Shaw, 2008; Warner et al., 2012).

Despite the high level of vulnerability to multiple natural hazards, coastal people of Bangladesh have a long tradition of employing various adaptation and coping measures to cope with these hazards (MEF, 2009; Ahmed, Haq, Nasreen, \& Hassan, 2015; Paul \& Routray, 2011). It has been argued that autonomous measures employed by people have largely been ignored and not integrated into a systematic approach, by either government or non-government organisations (Ahmed et al., 2015; Paul \& Routray, 2011). However, in recent years, the Government of Bangladesh has focused on community-based disaster risk management (MEF, 2009; DMB, 2010). The three major government policy documents related to climate change and disaster management are the Bangladesh Climate Change Strategy and Action Plan (BCCSAP) (MEF, 2009), the National Plan for Disaster Management 2010-2015 (NPDM) (DMB, 2010), and the National Disaster Management Policy (NDMP) (MDMR, 2015). These documents focus on community-based disaster risk reduction and climate change adaptation measures to strengthen community and household capacity to cope with natural hazards and the adverse effects of climate change. ${ }^{12}$

To strengthen community and household capacity, each of the three documents emphasises the need for interventions to be built on the understanding of the existing susceptibility of communities and households to natural hazards, and the adaptation and coping measures they currently use to deal with natural hazards and the adverse effects of climate change. Thus, a comprehensive understanding of what adaptation and coping measures households undertake to cope with natural hazards is essential in designing effective interventions that suit local needs and make households more resilient to natural hazards and the adverse impacts of climate change (DMB, 2010; MEF, 2009). However, adaptation and coping measures that households of the coastal areas of Bangladesh undertake to cope with natural hazards and the effectiveness of these measures have not been adequately investigated (Paul \& Routray, 2011).

To address this gap, this paper explores adaptation and coping measures that households of the coastal areas of Bangladesh undertake to minimise their vulnerability to two major natural hazards-cyclone and salinity intrusion. This paper is based on secondary sources. The first section of this paper describes the coastal area of Bangladesh; the second

\footnotetext{
1 Both NPDM and NDMP include natural, environment and human induced hazards.

2 Each of the three policy documents integrates disaster risk reduction measures and climate change adaptation measures as disaster risk reduction measures not only increase community and household level capacity to cope with natural hazards but also serve as adaptation measures to the adverse effects of climate change.
} 
presents the cyclone and salinity situation in coastal Bangladesh; and the third investigates adaptation and coping measures that

\section{Table 1: Sectoral Vulnerability by Hazards due to Climate Change in Bangladesh}

Physical Vulnerability Context

\begin{tabular}{|c|c|c|c|c|c|c|c|c|}
\hline \multirow{2}{*}{$\begin{array}{c}\text { Extreme } \\
\text { Temperature }\end{array}$} & \multicolumn{2}{|c|}{ Sea Level Rise } & \multirow[t]{2}{*}{ Drought } & \multicolumn{2}{|c|}{ Floods } & \multirow{2}{*}{$\begin{array}{c}\text { Cyclone } \\
\text { and } \\
\text { Storm } \\
\text { Surges }\end{array}$} & \multirow{2}{*}{$\begin{array}{c}\text { Erosion } \\
\text { and } \\
\text { Accretion }\end{array}$} & \multirow{2}{*}{$\begin{array}{c}\text { Sectoral } \\
\text { Vulnerability } \\
\text { Context }\end{array}$} \\
\hline & $\begin{array}{c}\text { Coastal } \\
\text { Inundation }\end{array}$ & $\begin{array}{c}\text { Salinity } \\
\text { Intrusion }\end{array}$ & & $\begin{array}{l}\text { River } \\
\text { Flood }\end{array}$ & $\begin{array}{l}\text { Flash } \\
\text { Flood }\end{array}$ & & & \\
\hline+++ & ++ & +++ & +++ & + & ++ & +++ & - & Crop \\
\hline & & & & & & & & Agriculture \\
\hline++ & + & + & ++ & ++ & + & + & - & Fisheries \\
\hline++ & ++ & +++ & - & - & + & +++ & - & Livestock \\
\hline+ & ++ & & - & ++ & + & + & +++ & Infrastructure \\
\hline++ & +++ & ++ & - & ++ & + & + & - & Industries \\
\hline++ & +++ & +++ & - & ++ & - & + & - & Biodiversity \\
\hline+++ & + & +++ & - & ++ & - & ++ & - & Health \\
\hline- & - & - & - & - & - & +++ & +++ & $\begin{array}{l}\text { Human } \\
\text { Settlement }\end{array}$ \\
\hline++ & + & - & - & + & - & + & - & Energy \\
\hline
\end{tabular}

Note: + + + refers to high, + + refers to moderate, and + refers to low level of relationship.

Source: MEF, 2005

\section{Coastal Areas of Bangladesh}

The coastal areas of Bangladesh include 30 per cent of the total land area of the country and have a population of 39.41 million, which is 27 per cent of the country's total population (Paul \& Rashid, 2017). Based on ecological and physiographic characteristics, the coastal area is divided into three zones: eastern, central, and western (Paul \& Rashid, 2017). The landward boundary of the coastal area has been determined based on three indicators: influence of tidal waters, salinity intrusion, and cyclones/storm surges (Ministry of Water Resources [MWR], 2005). Of the country's 64 districts, 19 belong to the coastal area. These 19 districts have a total of 147 upazilas (subunit of a district), with 48 of these located on the exposed coast and 99 on the interior coast (see Figure 1). The exposed coast meets the sea directly and the interior coast is situated behind the exposed coast. The exposed coast is highly vulnerable to natural hazards and to the impacts of sea level rise. About 60 islands and 177 char lands (accreted land) are identified in the coastal area (MWR, 2005; Sarwar, 2005).

The coastal areas of Bangladesh are prone to both natural and human-made hazards. These hazards have adversely affected lives and livelihoods and slowed down the pace of social and economic development in the coastal region (MWR, 2005). Furthermore, low income and poor housing and sanitation conditions have intensified the vulnerability of coastal communities (Parvin, Takahashi, \& Shaw, 2008). The vulnerability of the coastal areas of Bangladesh is being aggravated further by climate change and its adverse impacts. Saline water intrusion, extreme events, drainage congestion, and changes in coastal morphology have been identified as key vulnerabilities in the coastal area due to climate change (MEF, 2005, 2009). 


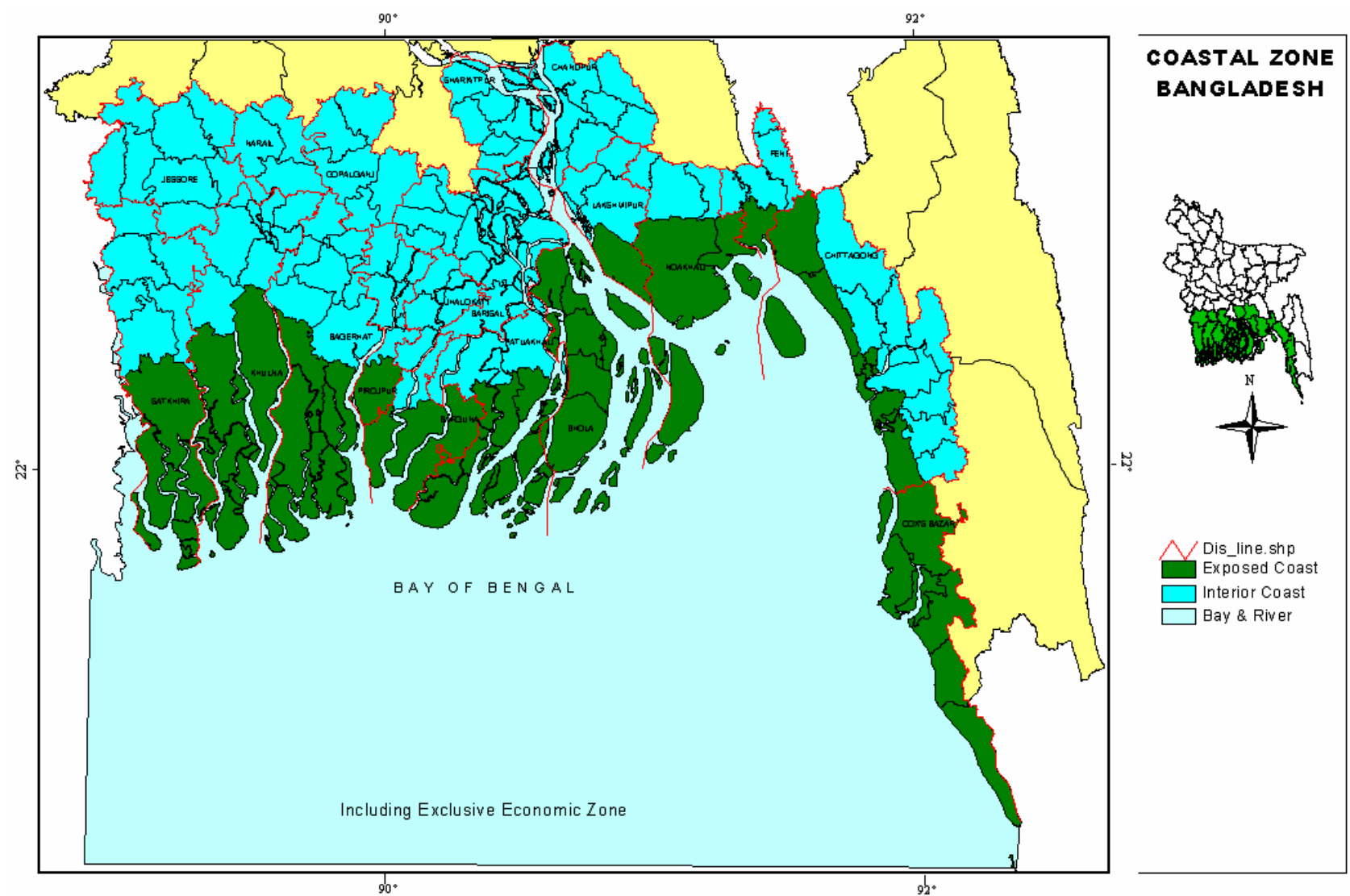

Figure 1: Coastal Area of Bangladesh

\section{Source: Sarwar (2005)}

Cyclones and Salinity Intrusion in the Coastal Areas of Bangladesh

\section{Cyclones}

The entire coastal area of Bangladesh, especially the islands and exposed upazilas, is a geographical 'death trap' because of its exposure to cyclones and associated storm surges (Ahmed, 2008; Parvin, Takahashi, \& Shaw, 2008; Saha \& James, 2017). Tropical cyclones with high winds and storm surges strike Bangladesh, on average, every three years (MEF, 2009; International Organisation for Migration [IOM], 2010), with the majority of cyclones striking Bangladesh during the April to early June and late September to November periods (United Nations Development Programme [UNDP], 2007). Cyclones have killed more than 450,000 people in Bangladesh since 1970 (United Nations [UN], 2010), with the majority of these deaths caused by two cyclones: the Bhola Cyclone (1970), which caused the deaths of 300,000 people, and Cyclone Gorky (1991), which killed 140,000 people (Department of Disaster Management
[DDM], 2013; Saha \& James, 2017). Table 2 outlines some of the major cyclones in Bangladesh.

\section{Salinity Intrusion}

Salinity is a major problem in some areas of coastal Bangladesh. About 6 million people are already exposed to high salinity ( $>5$ parts per thousand) and the number is expected to rise to 13.6 million by 2050 and 14.8 million by 2080 due to climate change. The population most affected by this will be of that located in the Bagerhat, Khulna and Satkhira districts (Pender, 2010). The increased severity and frequency of cyclones and the associated storm surges have also exacerbated the gradual increase in salinity levels (Warner et al., 2012).

Increased saline levels in the soil negatively affect rice production (Pender, 2010; Warner et al., 2012). It is argued that suitable areas for transplanted aman rice cultivation will decrease from 88 per cent to 60 per cent with a $32 \mathrm{~cm}$ rise in sea level in Bagerhat, Khulna and Satkhira districts (Pender, 2010). 


\begin{tabular}{|c|c|c|c|c|c|}
\hline Year & Date & $\begin{array}{l}\text { Maximum } \\
\text { wind speed } \\
(\mathrm{km} / \mathrm{hr})\end{array}$ & $\begin{array}{l}\text { Storm surge } \\
\text { height } \\
\text { (metres) }\end{array}$ & No. of deaths & $\begin{array}{l}\text { Main affected } \\
\text { districts }\end{array}$ \\
\hline 1965 & 11 May & 161 & $3.7-7.6$ & 19,279 & Barisal \\
\hline 1965 & 15 December & 217 & $2.4-3.6$ & 873 & Cox's Bazar \\
\hline 1966 & 01 October & 139 & $6.0-6.7$ & 850 & Noakhali \\
\hline $1970^{a}$ & $\begin{array}{l}12 \text { November } \\
(\text { Bhola })\end{array}$ & 224 & $6.0-10.0$ & 300,000 & Bhola \\
\hline 1985 & 25 May & 154 & $3.0-4.6$ & 11,069 & Noakhali \\
\hline 1991 & $\begin{array}{l}29 \text { April } \\
\text { (Gorky) }\end{array}$ & 225 & $6.0-7.6$ & 138,882 & $\begin{array}{l}\text { Cox's Bazar, } \\
\text { Chittagong }\end{array}$ \\
\hline 1997 & 19 May & 232 & $3.1-4.6$ & 155 & $\begin{array}{l}\text { Cox's Bazar, } \\
\text { Chittagong }\end{array}$ \\
\hline $2007^{b}$ & $\begin{array}{l}15 \text { November } \\
\text { (Sidr) }\end{array}$ & 223 & Up to 6.0 & 3363 & $\begin{array}{l}\text { Bagerhat, } \\
\text { Barguna, } \\
\text { Pirojpur, } \\
\text { Patuakhali }\end{array}$ \\
\hline $2009^{c}$ & $\begin{array}{l}25 \text { May } \\
(\text { Aila })\end{array}$ & 92 & Up to 6.5 & 190 & $\begin{array}{l}\text { Satkhira, } \\
\text { Khulna }\end{array}$ \\
\hline 2013 & $\begin{array}{l}16 \text { May } \\
\text { (Viyaru/Mahasen) }\end{array}$ & 85 & $1.0-1.5$ & 17 & $\begin{array}{l}\text { Barguna, Bhola, } \\
\text { Patuakhali }\end{array}$ \\
\hline $2015^{d}$ & $\begin{array}{l}30 \text { July } \\
\text { (Komen) }\end{array}$ & 70-90 & $0.91-1.5$ & 7 & $\begin{array}{l}\text { Cox's Bazar, } \\
\text { Chittagong, } \\
\text { Bandarban, } \\
\text { Noakhali, } \\
\text { Feni, } \\
\text { Bhola } \\
\end{array}$ \\
\hline 2016 & $\begin{array}{l}21 \text { May } \\
\text { (Roanu) }\end{array}$ & 100 & 2.7 & 27 & $\begin{array}{l}\text { Cox's Bazar, } \\
\text { Chittagong, } \\
\text { Barguna, Bhola, } \\
\text { Lakshmipur, } \\
\text { Noakhali, } \\
\text { Patuakhali }\end{array}$ \\
\hline
\end{tabular}

aNumber of deaths is 300,000-500,000 (United Nations Development Programme [UNDP], 2012).

bNumber of deaths is 4000 (UNDP, 2012).

'Number of deaths is 300 (Rashid \& Paul, 2014).

${ }^{d} W$ ind speed and storm surge for Komen are based on the situation report published before

the cyclone struck Bangladesh (Disaster Management Information Centre [DMIC], 2015).

Source: Saha \& James (2017)

A study based in Satkhira shows that 81 per cent of the 360 surveyed households suffer from high salinity in their rice fields, compared to only two per cent a decade ago (Warner et al., 2012). Salinity also diminishes productions of vegetables, fruits, and other crops; it also negatively affects other means of livelihood, such as pottery, as saline clay is not suitable for making ceramics (Pender, 2010).

Higher salinity levels in water sources also negatively affect people's health and wellbeing. Evidence suggests that high levels of 
salinity are associated with changes in menstruation of women and higher rates of miscarriage (Warner et al., 2012). Moreover, the consumption of salty water is partly responsible for an increased number of waterborne diseases, such as diarrhoea and dysentery, which primarily affect children (Warner et al., 2012; Paul \& Rashid, 2017). ${ }^{3}$ Increased salinity also causes stomach problems in cattle (Pender, 2010).

\section{Adaptation and Coping Measures Associated with Cyclones and Salinity Intrusion}

The terms 'adaptation' and 'coping' are sometimes used interchangeably, despite differences between them (van der Geest \& Warner, 2015; Warner et al., 2012; Monnereau \& Abraham, 2013; van der Geest \& Dietz, 2004; CARE International $[\mathrm{Cl}]$, 2009). Adaptation refers to 'longer-term adjustments to more permanent changes in the climate' while coping refers to 'short-term responses to the impacts of sudden or unusual events' (van der Geest \& Warner, 2015, p. 126). Adaptation is associated with longer-term livelihoods security, and sustainable use of resources, while coping is associated with short-term and immediate survival measures, often motivated by a crisis and prompted by a lack of alternatives $(\mathrm{Cl}$, 2009). Hence, it can be argued that the measures of adaptation help people to moderate harm or exploit beneficial opportunities, whilst coping measures aid people to face and manage adverse conditions, emergencies, or disasters by using available skills and resources (United Nations Office for Disaster Risk Reduction [UNISDR], 2009).

Coping measures can be categorised as either non-erosive or erosive coping measures (Warner et al., 2012; van der Geest \& Warner, 2015). Non-erosive coping measures do not jeopardise long-term or future livelihood security of households while erosive coping measures, despite the possibility of having

\footnotetext{
3 Although the current recommended dietary intake of sodium is $2 \mathrm{~g} /$ day, the population of Dacope Upazila, Khulna District, consume 5 to $16 \mathrm{~g} /$ day sodium during the dry season in drinking water alone, depending on drinking water source (Khan et al., 2011).
}

short-term benefits, jeopardise long-term or future livelihood security of households (Warner et al., 2012; van der Geest \& Warner, 2015). Thus, coping measures are successful when households allocate resources to overcome a crisis without compromising the long-term livelihood security, though coping measures are unsuccessful when households employ measures to overcome a crisis that undermine their long-term livelihood security.

Households in the coastal areas of Bangladesh undertake various adaptation and coping measures to manage the adverse impacts of cyclones and salinity intrusion. Despite this, access to and control over the resources (natural, human, social, physical, and financial resources) that are necessary for the adoption of these measures vary among communities (such as a village), and even among households within a community (Cl, 2009; Blaikie, Cannon, Davis, \& Wisner, 1994). Adaptation and coping measures adopted by households are dependent on many factors, such as the social, cultural, and economic background of the households; physical location; the nature of the hazards; and household's level of vulnerability and ability to absorb shock (Parvin, Takahashi, \& Shaw, 2008; Paul \& Routray, 2011; Saha, 2016). Although this paper does not deal with variations in adopting adaptation and coping measures based on the aforementioned factors, it is worth mentioning that-based on these factors-measures undertaken by households vary within a community, between communities within a coastal region, as well as among the three coastal regions of the coastal Bangladesh (Paul \& Routray, 2011; van der Geest \& Dietz, 2004; van der Geest \& Warner, 2015).

\section{Adaptation and Coping Measures Associated with Cyclones}

Adaptation and coping measures associated with cyclone hazards can be categorised into three stages (although some measures may not be exclusive to a particular stage): pre-cyclone (long-term adaptation and when a cyclone is imminent), just prior to and during cyclone, and post-cyclone. 
Households undertake various long-term adaptation measures to reduce their vulnerability to cyclones. They build houses on a raised earth platform to protect family members and belongings during cyclones, avoid housing materials that are susceptible to surge water, and construct houses in a way so that houses face less wind forces (see Figure 2 and Figure 3) (Alam \& Collins, 2010; Paul \& Routray, 2011). Moreover, some people plant bigbranched trees around the homestead to protect life, houses and properties from wind and storm surges (Alam \& Collins, 2010; Paul \& Routray, 2011; Garai, 2017).

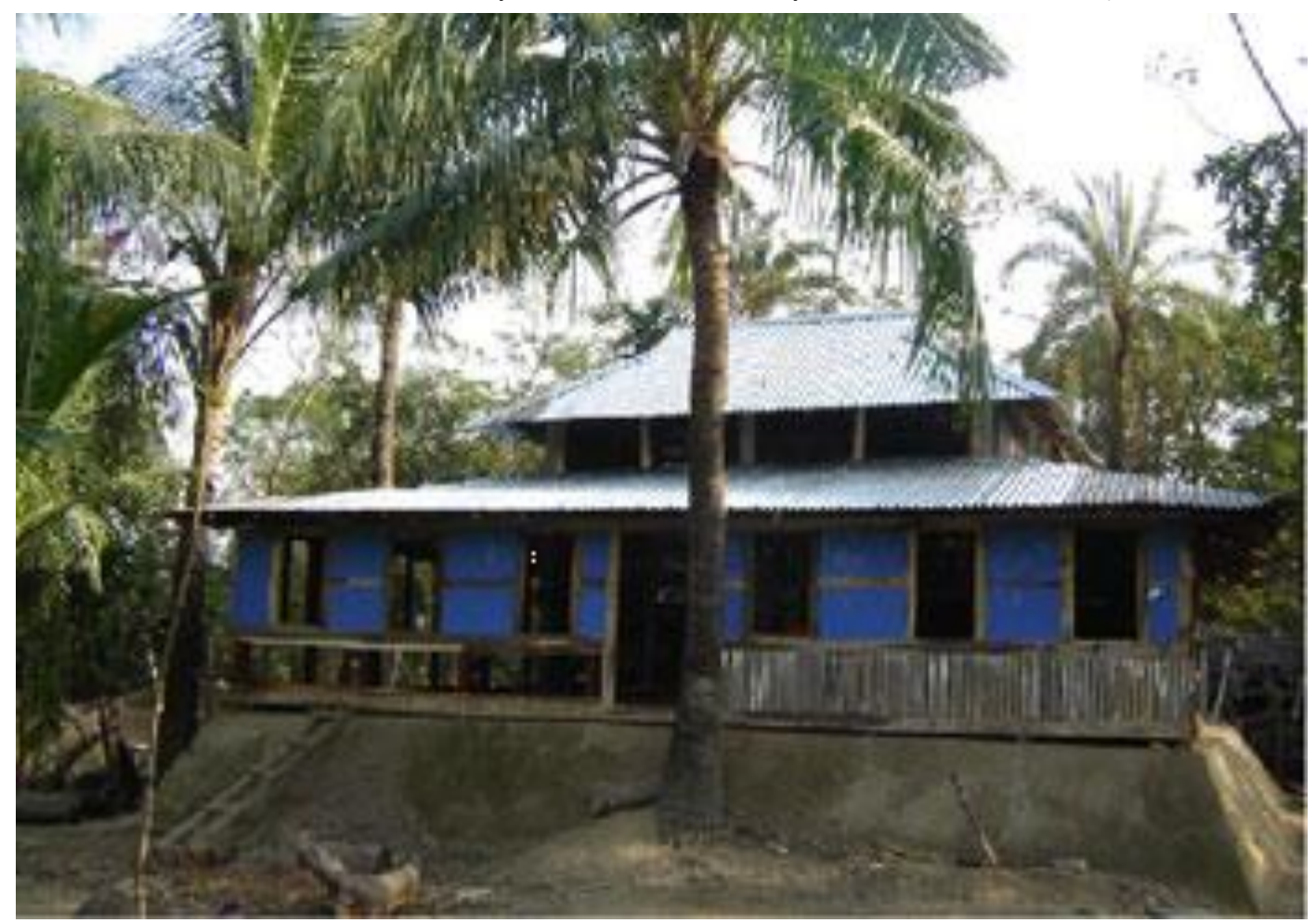

Figure 2: A Temple-shaped House on a Raised Earth Platform

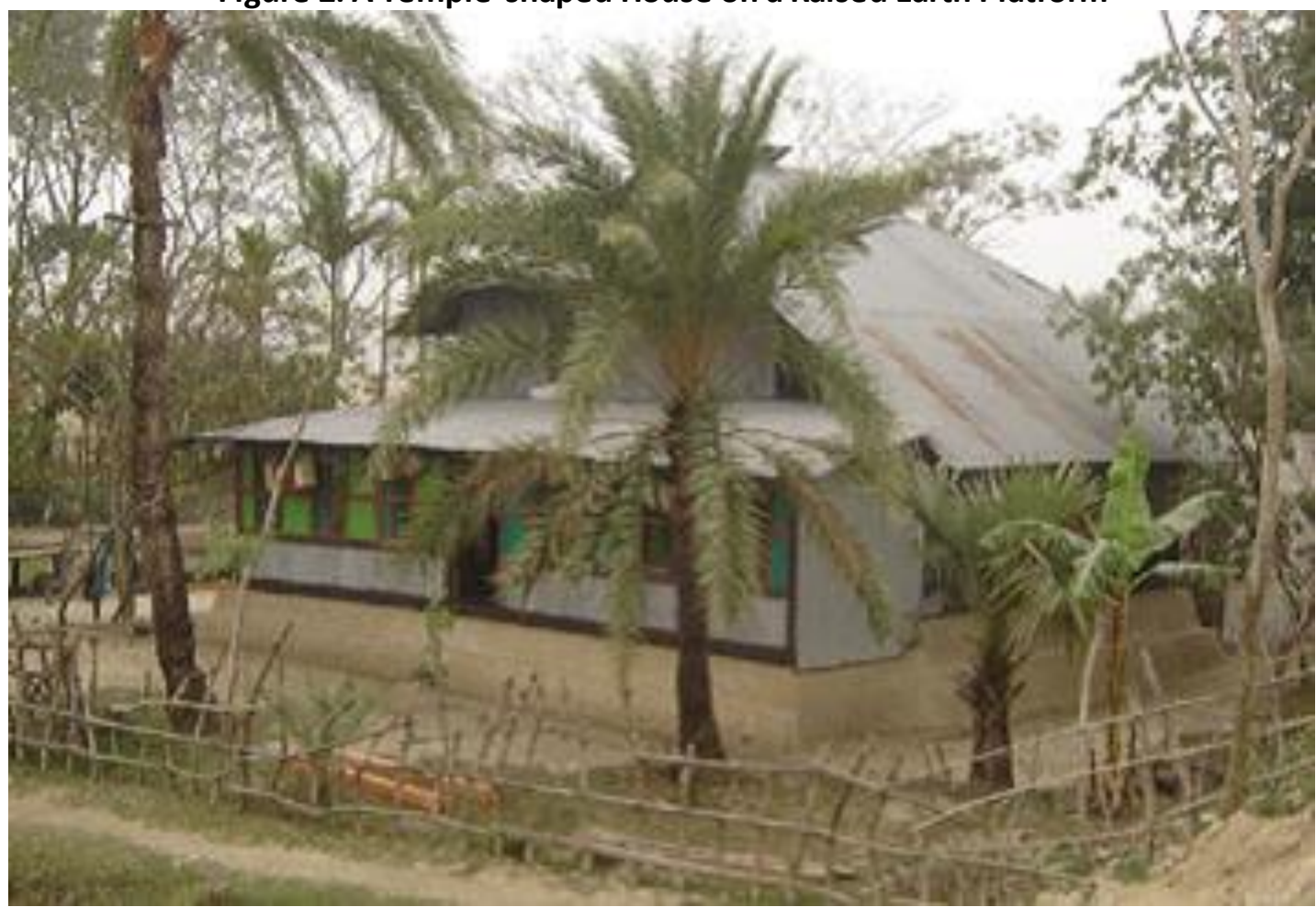

Figure 3: A House Designed to Face Less Wind Forces During Cyclones (Gentle Sloping of the Roof of the House) 
Households also undertake some measures to reduce their vulnerability to cyclones when a cyclone is imminent. Such measures include: collecting crops from fields; hiding valuables and food in the earth; tying houses to adjacent big trees using strong ropes; inserting new poles around the houses if houses are not made of brick; sending important things to relatives living in safer areas; increasing religious activities; and sending domestic animals to highland areas or untying domestic animals so that they can survive surge water if the warning signal is at or close to the highest danger (Alam \& Collins, 2010; Parvin, Takahashi, \& Shaw, 2008; Paul \& Routray, 2011; Garai, 2017).

Just prior to and during the cyclone and induced storm surge, people try to save themselves by taking refuge in safe places, such as cyclone shelters, neighbouring houses, or in the ceilings of their houses (Alam \& Collins, 2010; Paul \& Routray, 2011; Garai, 2017).

There are multiple tasks that people do during the post-cyclone period, such as: searching for friends and family; looking for materials needed to rebuild houses; taking dried food that had been stored as precaution, or whatever food is available to them, such as wetted rice, bread and sweet potato, before outside help arrives; arranging community cooking for several days; travelling a long distance to collect water; using tablets to purify water; searching for means of livelihoods; reducing the number of meals per day and relying on inexpensive foods, such as flattened rice and gur; seeking assistance from relatives, neighbours and unaffected local people; relying on relief; using savings; going to cities for work; taking out loans, including conditional loans, from various sources such as relatives, friends, money lenders and local NGOs; and selling assets, such as land, cattle, fishing and agricultural equipment (Alam \& Collins, 2010; Parvin, Takahashi, \& Shaw, 2008; Paul \& Routray, 2011; Saha, 2016, Garai, 2017).

It is worth noting that some of the measures that households undertake during the postcyclone period-such as reducing the number of meals per day, taking out loans (particularly conditional loans from money lenders), and selling assets-are erosive coping measures as these measures risk households' food and livelihood security and make them more vulnerable. These erosive coping measures are very common in the coastal areas of Bangladesh. For instance, a study conducted in the three villages of Barguna and Patuakhali districts of Bangladesh shows that more than 90 per cent of the surveyed households reduced the number of meals per day to cope with the crisis following a cyclone (Paul \& Routray, 2011). These erosive coping measures are mainly linked to poverty and a lack of an alternative livelihood, or livelihood stress resulting from the failure to secure income after the cyclone, as the cyclone adversely affects or destroys livelihoods of households, particularly households that are dependent on agriculture or on selling agricultural labour (Saha, 2016, Rabbani, Rahman, \& Mainuddin, 2013).

\section{Adaptation and Coping Measures Associated with Salinity Intrusion}

Households in the coastal areas of Bangladesh undertake several measures to adapt and cope with the changing conditions associated with increased salinity intrusion (see Figure 4). These measures can be categorised as field or agricultural-based measures and non-field or non-agricultural-based measures. Households employ agricultural-based measures to reduce the negative effect of salinity intrusion on agricultural production, while they employ nonagricultural measures to reduce livelihood dependency on agriculture (Rabbani, Rahman, \& Mainuddin, 2013). The two main agriculturalbased measures that households undertake are using new saline-tolerant rice cultivars and reducing the salinity content of soil by washing rice fields with fresh water (see Table 3) (Mainuddin, Rahman, Islam, and Quasem, 2011; Warner et al., 2012; Rabbani, Rahman, \& Mainuddin, 2013). To flush freshwater through agricultural fields to reduce salinity, farmers dig canals or purchase fresh water from neighbouring canals and ditches (Mainuddin et al., 2011; Warner et al., 2012). Other 
agricultural-based measures include raising seedbeds with fresh soil (Warner et al., 2012; Rabbani, Rahman, \& Mainuddin, 2013), using fertilisers to prevent soil salinity (Khanom, 2016; Pouliotte, Islam, Smit, \& Islam, 2006), and applying sugar to the rice fields to reduce salinity (Warner et al., 2012).

Another measure that is related to agriculture is converting croplands into shrimp farms, which in turn contributes to the increased salinity intrusion (Pouliotte et al., 2006; Khanom, 2016; Swapan \& Gavin, 2011). For instance, a study reveals that almost 90 per cent of the land previously used for rice and vegetable production has been converted into shrimp ponds in the study area located in Koyra Upazila of Khulna District of Bangladesh (Swapan \& Gavin, 2011). However, in addition to having severe negative ecological impacts, shrimp farming as a response to saltwater intrusion does not equally benefit all households that convert agricultural lands into shrimp ponds. Although shrimp farming offers significant benefits for large landowning households, small landowners and other poor and landless households do not usually benefit from this new livelihood opportunity (Pouliotte et al., 2006; Swapan \& Gavin, 2011).

Non-agricultural measures that households employ include taking out loans from nongovernmental organisations, neighbours, and relatives; increasing the number of hours worked to earn more; increasing the number of household members (generally women or children) working for a wage income; reducing household expenditure; migrating elsewhere to find work; selling household assets, including land and livestock; leasing out the land to others; changing eating habits; raising goats as an alternative to cattle; and switching to nonfarm activities such as rickshaw/van pulling (Rabbani, Rahman, \& Mainuddin, 2013; Pouliotte et al., 2006). A study conducted in four villages of Shyamnagar Upazila of the Satkhira District shows that more than 70 per cent households took out loans, reduced household expenditure and changed eating habits to cope with the impact of salinity intrusion on rice production. Additionally, 55 per cent of households tried to earn more by increasing working hours; about 30 per cent employed temporary migration of a household member/(s); 25 per cent switched to non-farm activities; and about 23 per cent sold household assets to cope with the impact of salinity intrusion on rice production (Rabbani, Rahman, \& Mainuddin, 2013).

Salinity also has a gendered dimension, as women are traditionally responsible for collecting water for drinking and cooking. Women are trying to adapt to the scarcity of fresh water, due to salinity, by collecting rainwater or developing a jar filter system and a pond sand filter system to get fresh water from saline water. Other than these three practices, women collect water from very deep tube wells by walking a long distance, which may take three to four hours a day. This naturally results in health hazards (Ahmed, 2008; Rahman, 2009).

Table 3: Measures Undertaken at the Household Level to Cope with Salinity Intrusion in Bagerhat, Khulna and Satkhira districts of Bangladesh

Study Area Cultivate Saline-resistant Crops

(\% of Households)
Dig Canals for the Irrigation of

Fresh Water (\% of

Households)

\begin{tabular}{llrccc} 
& Yes & No & No response & Yes & No \\
\hline Bagerhat & 48 & 49 & 3 & 14.9 & 85.1 \\
\hline Khulna & 91 & 4 & 5 & 27.6 & 72.4 \\
\hline Satkhira & 85 & 12 & 3 & 42.6 & 57.4
\end{tabular}

Source: Mainuddin et al. (2011) 


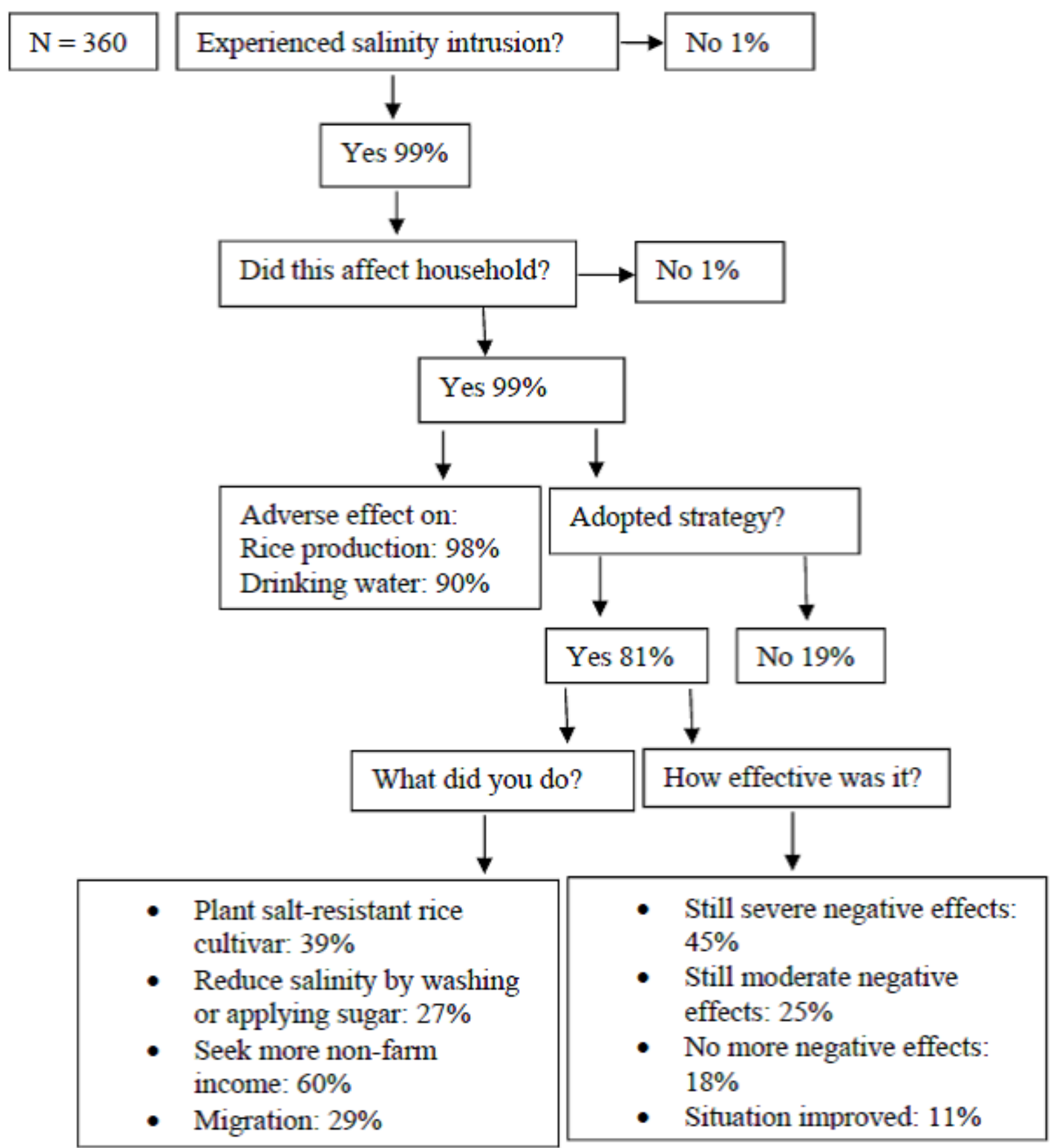

Figure 4: Measures Undertaken at the Household Level to Cope with Salinity Intrusion in Four Villages of Satkhira District,

Source: Warner et al. (2012)

\section{Conclusion}

Households in the coastal areas of Bangladesh are relentlessly trying to reduce their vulnerability to cyclone hazards and salinity intrusion by undertaking various adaptation and coping measures. However, while many of these adaptation and coping measures reduce their vulnerability, and enhance resilience, some of the undertaken coping measures, such as reducing the number of meals per day and selling households' assets-including land and livestock-are erosive coping measures as they jeopardise their food and livelihood security. Despite helping households to address immediate needs and overcome a crisis, these erosive coping measures make households more vulnerable instead of making them resilient. These erosive coping measures may, at worst, result in the complete destitution of households.

Adaptation and coping measures that contribute to reduce households' vulnerability should be supported and guided by the government and NGOs to make them more 
effective. Erosive coping measures that make households further vulnerable also need to be addressed by the government and NGOs since most of these coping measures are related to poverty and households' limited-if any-access to economic opportunities. One of the most important actions that need to be undertaken by the government and NGOs is the creation of alternative livelihood opportunities for coastal communities, since livelihood stress is one of the major factors that increase their vulnerability to natural hazards (Saha, 2016; Pouliotte et al., 2006; MEF, 2009). Finally, supporting measures that make a positive contribution, and addressing those measures that are making households more vulnerable to natural hazards, is only possible when disaster risk reduction activities instigated by the government and NGOs can be integrated with the activities undertaken by households and communities to reduce vulnerability to natural hazards.

\section{References}

Ahmed, A. U. (2008). Assessment of Vulnerability to Climate Change and Adaptation Options for the Coastal People of Bangladesh. Dhaka, Bangladesh: Practical Action.

Ahmed, A. U., Haq, S., Nasreen, M., \& Hassan, A. W. (2015). Sectoral Inputs towards the Formulation of Seventh Five-Year Plan (2016 - 2021): Climate Change and Disaster Management (Rep.). Retrieved April 30, 2017, from http://plancomm.gov.bd/wpcontent/uploads/2015/02/11a_ClimateChange-and-Disaster-Management.pdf

Alam, E., \& Collins, A. E. (2010). Cyclone Disaster Vulnerability and Response Experiences in Coastal Bangladesh. Disasters, 34(4), 931-954. doi:10.1111/j.1467-7717.2010.01176.x

Blaikie, P., Cannon, T., Davis, I., \& Wisner, B. (1994). At Risk: Natural Hazards, People's Vulnerability and Disasters. London: Routledge.
Care International. (2009). Climate Vulnerability and Capacity Analysis Handbook (First Edition). Retrieved February 3, 2017, from

http://www.careclimatechange.org/files /adaptation/CARE_CVCAHandbook.pdf

Department of Disaster Management. (2013). Emergency Preparedness Plan for Cyclone. Dhaka, Bangladesh: Ministry of Disaster Management and Relief.

Disaster Management Bureau. (2010). National Plan for Disaster Management 20102015. Dhaka, Bangladesh: Disaster Management and Relief Division. Retrieved May 1, 2017, from http://modmr.portal.gov.bd/sites/defau It/files/files/modmr.portal.gov.bd/law/4 9c13857_0831_474f_bb64_f8d7db0eb4 ac/Nataional_Plan_for_Disaster_2010_ 2015_Final_Version-.pdf

Disaster Management Information Centre. (2015). Situation Report. Dhaka, Bangladesh: Ministry of Disaster Management and Relief. Retrieved May 1, 2017, from http://reliefweb.int/sites/reliefweb.int/f iles/resources/SitRep-150730.pdf

Garai, J. (2017). Qualitative Analysis of Coping Strategies of Cyclone Disaster in Coastal Area of Bangladesh. Natural Hazards, 85(1), 425-435. doi: 10.1007/s11069$016-2574-8$

International Organisation for Migration. (2010). Assessing the Evidence: Environment, Climate Change and Migration in Bangladesh. Dhaka, Bangladesh.

Khan, A. E., Ireson, A., Kovats, S., Mojumder, S. K., Khusru, A., Rahman, A., \& Vineis, P. (2011). Drinking Water Salinity and Maternal Health in Coastal Bangladesh: Implications of Climate Change. Environmental Health Perspectives, 119(9), 1328-1332.

Khanom, T. (2016). Effect of Salinity on Food Security in the Context of Interior Coast 
of Bangladesh. Ocean \& Coastal Management, 130, 205-212. doi:10.1016/j.ocecoaman.2016.06.013

Mainuddin, K., Rahman, A., Islam, N., \& Quasem, S. (2011). Planning and Costing Agriculture's Adaptation to Climate Change in the Salinity-prone Cropping System of Bangladesh (Publication). London, UK: International Institute for Environment and Development. Retrieved February 3, 2017, from http://pubs.iied.org/pdfs/G03173.pdf

Ministry of Disaster Management and Relief. (2015). National Disaster Management Policy. Dhaka, Bangladesh. Retrieved May 1, 2017, from http://modmr.portal.gov.bd/sites/defau It/files/files/modmr.portal.gov.bd/polici es/d95dd631_9f63_4ac1_8229_a606ec 84fb54/Published\%20DM\%20Policy\%20 2015.pdf

Ministry of Environment and Forests. (2005). National Adaptation Programme of Action (NAPA). Dhaka, Bangladesh. Retrieved February 3, 2017, from: http://unfccc.int/resource/docs/napa/b an01.pdf

Ministry of Environment and Forests. (2009). Bangladesh Climate Change Strategy and Action Plan 2009. Dhaka, Bangladesh. Retrieved May 1, 2017, from

http://www.climatechangecell.org.bd/D ocuments/climate_change_strategy200 9.pdf

Ministry of Water Resources. (2005). Coastal Zone Policy. Dhaka, Bangladesh. Retrieved January 17, 2017, from http://lib.pmo.gov.bd/legalms/pdf/Cost al-Zone-Policy-2005.pdf

Monnereau, I., \& Abraham, S. (2013). Limits to Autonomous Adaptation in Response to Coastal Erosion in Kosrae, Micronesia. International Journal of Global Warming, 5(4), 416-432. doi:10.1504/ijgw.2013.057283
Parvin, G. A., Takahashi, F., \& Shaw, R. (2008). Coastal Hazards and Community-Coping Methods in Bangladesh. Journal of Coastal Conservation, 12(4), 181-193. doi: $10.1007 / \mathrm{s}$ 11852-009-0044-0

Paul, B. K., \& Rashid, H. (2017). Climatic Hazards in Coastal Bangladesh: NonStructural and Structural Solutions. Butterworth-Heinemann Publications, Elsevier Inc.

Paul, S. K., \& Routray, J. K. (2011). Household Response to Cyclone and Induced Surge in Coastal Bangladesh: Coping Strategies and Explanatory Variables. Natural Hazards, 57(2), 477-499. doi: $10.1007 / \mathrm{s} 11069-010-9631-5$

Pender, J. S. (2010). Climate Change, its Impacts and Possible Community-Based Responses in Bangladesh (Second Edition). Dhaka, Bangladesh: Church of Bangladesh. Retrieved February 3, 2017, from

http://uploads.ecocongregationscotland .org/uploads/Climate\%20Change\%20in \%20Bangladesh_Sept\%202010.pdf

Pouliotte, J., Islam, N., Smit, B., \& Islam, S. (2006). Livelihoods in Rural Bangladesh (pp. 18-22, 59). Tiempo. Retrieved February 3, 2017, from http://www.uoguelph.ca/gecg/images/ userimages/Pouliotte\%20et\%20al.\%20 (2006).pdf

Rabbani, G., Rahman, A., \& Mainuddin, K. (2013). Salinity-induced Loss and Damage to Farming Households in Coastal Bangladesh. International Journal of Global Warming, 5(4), 400415. doi:10.1504/ijgw.2013.057284

Rahman, M. A. (2009). Salt Is Killing Us: Salinity and Livelihood in Bangladesh Village (Unpublished Master's thesis). Lund University. Retrieved February 3, 2017, from

http://lup.lub.lu.se/luur/download?func $=$ downloadFile \& recordOId $=1529179 \&$ fil eOId $=1543283$ 
Rashid, H., \& Paul, B. K. (2014). Climate Change in Bangladesh: Confronting Impending Disasters. Lanham: Lexington Books.

Saha, S. K. (2016). Cyclone Aila, Livelihood Stress, and Migration: Empirical Evidence from Coastal Bangladesh. Disasters. doi:10.1111/disa.12214

Saha, S. K., \& James, H. (2017). Reasons for Non-Compliance with Cyclone Evacuation Orders in Bangladesh. International Journal of Disaster Risk Reduction, 21, 196-204. doi:10.1016/j.ijdrr.2016.12.009

Sarwar, M. G. (2005). Impacts of Sea Level Rise on the Coastal Zone of Bangladesh (Unpublished Master's thesis). Lund University. Retrieved February 3, 2017, from http://www.pg-du.com/wpcontent/uploads/2012/02/golam_sarwa r.pdf

Swapan, M. S., \& Gavin, M. (2011). A Desert in the Delta: Participatory Assessment of Changing Livelihoods Induced by Commercial Shrimp Farming in Southwest Bangladesh. Ocean \& Coastal Management, 54(1), 45-54. doi:10.1016/j.ocecoaman.2010.10.011

United Nations. (2010). Cyclone Aila: Joint UN Multi-sector Assessment and Response Framework. Retrieved July 22, 2016, from

http://www.lcgbangladesh.org/derweb/ Needs\%20Assessment/Reports/Aila_UN _AssessmentFramework_FINAL.pdf

United Nations Development Programme. (2007). UNDP Human Development Report 2007 Background Paper on Risks, Vulnerability and Adaptation in Bangladesh. New York, USA: UNDP. Retrieved February 3, 2017, from http://hdr.undp.org/sites/default/files/r ahman_alam_alam_uzzaman_rashid_ra bbani.pdf

United Nations Development Programme. (2012). Review of Development Partners' Response to Cyclone Aila. New York, USA. Retrieved February 3, 2017, from http://www.solutionexchangeun.net/repository/bd/cdrr/update14res1-en.pdf

United Nations International Strategy for Disaster Risk Reduction. (2009). 2009 UNISDR Terminology on Disaster Risk Reduction. Geneva, Switzerland: UNISDR.

Van der Geest, K., \& Dietz, T. (2004). A Literature Survey about Risk and Vulnerability in Drylands, with a Focus on the Sahel. In The Impact of Climate Change on Drylands, with a focus on West Africa (Vol. 39, Environment \& Policy, pp. 117-146). Dordrecht, The Netherlands: Kluwer Academic.

Van der Geest, K., \& Warner, K. (2015). Vulnerability, Coping and Loss and Damage from Climate Events. In Hazards, Risks, and Disasters in Society (pp. 121-144). Elsevier. doi:10.1016/B978-0-12-3964519.00008-1

Warner, K., Van der Geest, K., Kreft, S., Huq, S., Harmeling, S., Kusters, K., \& Sherbinin, A. D. (2012). Evidence from the Frontlines of Climate Change: Loss and Damage to Communities despite Coping and Adaptation (Publication No. 9). Retrieved February 3, 2017, from http://loss-anddamage.net/download/6815.pdf

\section{Acknowledgements}

The author is thankful to the editor and the two anonymous reviewers for their constructive comments to improve the article. 